\title{
Quality of Life Level Description of Elderly Patients with Hypertension Using Instruments WHOQOL- BREF
}

\author{
(Ciereng Hospital, Subang)
}

\author{
Jusron Iriawan* \\ Department of Internal Medicine \\ Jenderal Achmad Yani University \\ Cimahi, Indonesia \\ *yusron.iriawan@fk.unjani.ac.id
}

\author{
Ghaisani Nur Shabrina, Ali Taufan, Muhammad Adam \\ Zulqarnain \\ Faculty of Medicine \\ Jenderal Achmad Yani University \\ Cimahi, Indonesia \\ adam.zulqarnain77@gmail.com
}

\begin{abstract}
Aging or elderly were the most growing population group and continued to increase as a proportion of the world population. Elderly were the most susceptible age group to physical complaints, either due to physiological factors or disease. Most diseases experienced by the elderly were hypertension. According to Riskesdas, West Java Province figured hypertension in Subang at $35.4 \%$, or at the 4th in West Java. Hypertension in the elderly causes problems both from physical health, psychological, social relations, and environmental, resulting in decreased quality of life of sufferers. The study design was a descriptive study to know the level of quality of life of elderly patients with hypertension using instruments WHOQOL-BREF in Ciereng Subang hospital. The total sample in this study are 93 people by using a simple random sampling technique. Respondent data consist of 45 males $(48,4 \%)$ and 48 females $(51,6 \%)$. The results showed that the quality of life of the elderly in general quality of life was moderate $(\mathbf{5 5 . 9 \% )}$ while a good quality of life $(32.3 \%)$, the dimensions of physical health got a poor quality of life $(60.2 \%)$, the dimensions of psychological well-being got a poor quality of life $(52.7 \%)$, the social relationship dimension being got a moderate quality of life $\mathbf{7 9 . 6 \%}$ ) and on the relation between environmental dimension got a moderate quality of life $(\mathbf{8 3 . 8 \%})$. The conclusion of this study is quality of life of the elderly in general is good, only bad on the dimensions of physical health and psychological wellbeing.
\end{abstract} BREF

Keywords-elderly, hypertension, quality of life, WHOQOL-

\section{INTRODUCTION}

An elderly person according to WHO is someone aged 60 years or more [1]. Some developed countries that already have a better standard of living in the economic and health sectors, such as countries in Europe and America, consider the limitation for elderly people to be 65 years $[1,2]$.
The population of the elderly continues to increase in line with the increase in the world's population, which increased from $9.2 \%$ in 1990 to $11.7 \%$ in 2013 and is projected to reach $21.1 \%$ in 2050 [3]. World demographic data shows that the increase in the elderly population has tripled in size. A period of 50 years, from 600 million in 2000 to more than 2 billion in $2050[2,4]$.

The increase in the prevalence of the elderly is faster than the population of other age groups due to the success of development in various fields, especially health, thus increasing life expectancy and decreasing birth rates in the world. This increase will grow faster in developing countries including Indonesia [3-6].

In Indonesia, the number of elderly people in 2014 was 20.24 million or around $8.03 \%$ of the total population [5]. It is projected that in 2050 the percentage will increase quite rapidly, namely around $21.4 \%$ [6]. The number of elderly people in Indonesia will reach five the largest number in the world, namely 18.1 million in 2010 , and will double to 36 million by 2025 [7]. According to the demographic data of the international population released by the Bureau of the Census USA, it was reported that in 1990-2025 the increase. The number of elderly people in Indonesia is $414 \%$ which is the highest number in the whole world $[2,4]$.

The elderly will experience a biological process beyond human control called the aging process. There are many theories that explain the aging process from biological, social, and psychological theories [7]. The aging process will have an impact on various aspects of life, be it social, economic, and health. In terms of health, with increasing age, the elderly are more susceptible to various physical complaints, both due to physiological factors and because of disease [6]. Disability and death in the elderly can occur due to hearing, vision, movement, and decreased function of organ systems such as 
sensory systems, central nervous, digestive, cardiovascular, and respiratory systems [6-8].

Diseases of the cardiovascular system are a major cause of death and disability in the elderly. Hypertension is one of the most common problems experienced by the elderly and is a major risk factor for cardiovascular disease. Hypertension is a condition when the blood pressure in the blood vessels increases chronically. This results in the heart working harder to pump blood to meet the body's oxygen and nutritional needs. According to the Joint National Committee VIII, hypertension is found when there is an increase in systolic blood pressure $\geq 140 \mathrm{mmHg}$ and diastolic pressure $\geq 90 \mathrm{mmHg}[7,9,10]$.

Based on the cause, hypertension consists of primary and secondary hypertension. Primary hypertension is a multifactorial disease that arises because of the interaction between certain risk factors. Age is one of the factors that influence hypertension because the elderly have experienced a reduction in arterial elasticity or a sclerosis process occurs, especially in large arteries, resulting in higher systolic pressure and lower diastolic pressure or an increase in pulse pressure [10-12].

The number of people with hypertension continues to increase with the increasing age of the population. According to the Seventh Report of the Joint National Committee on Prevention, Detection, Evaluation, and Treatment of High Blood Pressure (JNC-7), hypertension occurs in more than two-thirds of individuals after the age of 65 [13]. According to the Indonesian Ministry of Health, hypertension was the most common disease suffered by the elderly in 2013. Based on the 2013 Riskesdas Balitbangkes results, hypertension appeared to increase according to the increasing age of the respondent. The prevalence of hypertension in Indonesia is $26.5 \%$ and is found in respondents aged 55-64 years (45.9\%), 65-74 years $(57.6 \%)$, and $75+$ years $(63.8 \%)[6,14]$.

Based on data from Riskesdas in West Java Province in 2013, the prevalence of hypertension in Subang district was $35.4 \%$ or the fourth highest in West Java after Kab. Kuningan, Majalengka and Garut. RSUD Ciereng Subang shows data that hypertension is also a major health problem where hypertension is in the top ten diseases [15].

The increase in the number of hypertensive patients in the elderly can lead to a decrease in the quality of life. In a study conducted by Trevisol et al. in Brazil, it was found that individuals suffering from hypertension have a lower quality of life than individuals with normal blood pressure [16]. Research by Dewi and Sudhanan in Bali shows that the quality of life is poor In hypertensive patients from the physical health dimension $(73.3 \%)$ and the quality of life from the bad psychological dimension is the highest number, namely $73.3 \%$ [17].
Quality of life according to the World Health Organization (WHO) is a person's perception in the context of culture and norms in accordance with the person's place of life and is related to the goals, hopes, standards, and concerns of his life. Assessment of quality of life in this study used the WHOQOLBREF (World Health Organization Quality of Life-BREF) instrument in the form of a questionnaire consisting of 26 questions consisting of four domains, namely the physical health dimension consisting of 7 questions, the dimension of psychological well-being (psychological) 6 questions, dimensions of social relations (social relationship) 3 questions, as well as dimensions of the relationship with the environment (environment) 8 questions and 2 facets of the quality of life in general, namely the overall quality of life (overall quality of life) and health in general (general health) [18]

Oktavianus et al. have tested that the WHOQOLBREF instrument is a valid and reliable instrument for measuring the quality of life in the elderly [19]. At Ciereng Subang Hospital, this research has never been carried out so that researchers are interested in conducting research related to the description of the quality of life of elderly patients with hypertension using the WHOQOL-BREF instrument at Ciereng Hospital, Subang.

\section{METHODS}

The study design was a descriptive study to know the level of quality of life of elderly patients with hypertension using instruments WHOQOL-BREF in Ciereng Subang hospital. The subjects of this study were elderly patients who had hypertension without complications at Ciereng Subang Hospital and were willing to be research subjects (informed consent). Total sample in this study are 93 people by using a simple random sampling technique. The data which obtained from the interviews then analyzed using WHOQOL-BREF which have 26 questions consisting of four domain. Score on each dimension were counted using following equation formula:

Physical health: (6-Q3)+(6-Q4)+Q10+Q15+Q16+Q17+Q18

Psychological health: Q5+Q6+Q7+Q11+Q19+(6-Q26)

Social relations: Q20+Q21+Q22

Environmental relations: Q8+Q9+Q12+Q13+Q14+Q23+Q24+ Q25

The next step was transformed each raw scale score to a 0 100 scale using the formula show below:

Transformed Scale $=\left[\frac{(\text { Actual raw score }- \text { lowest possible raw score })}{\text { Possible raw score range }}\right] \times 100$

If the score 0-33 then the patient got a poor quality of life, 34-66 got a moderate quality of life, 67-100 got a good quality of life. 


\section{RESULTS AND DISCUSSION}

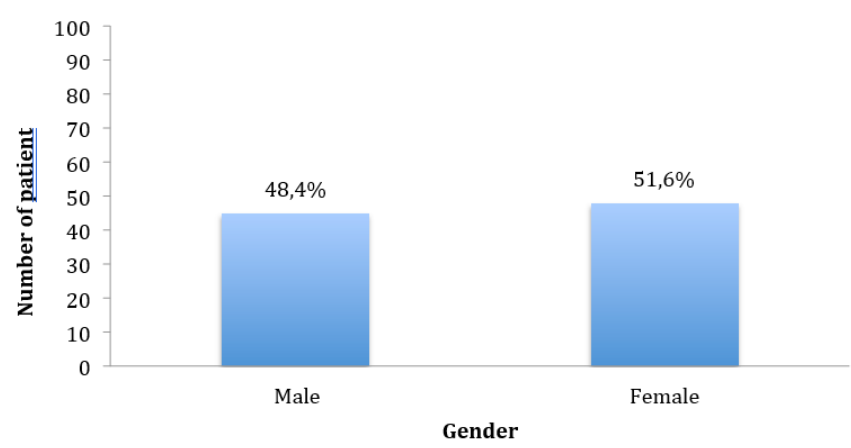

Fig. 1. Respondent characteristic by gender.

Fig. 1 show that characteristics of respondents in elderly patients with hypertension at Ciereng Subang Regional Hospital based on gender consisted of 45 men $(48.4 \%)$ and 48 women $(51.6 \%)$.

Gender is one of the uncontrollable risk factors that also affect blood pressure. Several studies have shown that up to the age of 54 men are more likely to develop hypertension than women. But as the age increases, from the age of 55 years to 64 years men and women have the same risk and at the age of 65 years or more women are more susceptible to hypertension than men. This is because the hormonal role in women and one of the characteristics of menopause is marked by an increase in blood pressure according to the results of the NHANES III study [11,20-24].

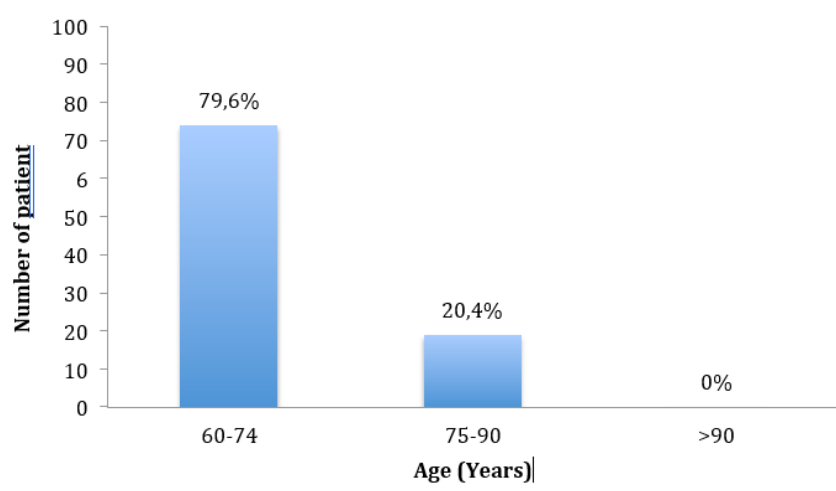

Fig. 2. Respondent characteristic by age.

Fig. 2 show that the age group in this study were at most 60-74 years as many as 74 people $(79.6 \%)$, $75-90$ years as many as 19 people (20.45\%), and there were no patients over 90 years. The older the age, the higher a person's risk of chronic disease, especially in the elderly. The decrease in elasticity of the arteries occurs as you age, which results in increased blood pressure $[11,20,21]$.
Framingham's research shows that hypertensive patients have an increase in cardiovascular mortality three times higher than normotension and this is more significant in women after 65 years of age $[11,20,22]$.

Elderly groups have a tendency to blood pressure lability and easy postural hypotension so that when taking measurements it is recommended to be in a sleeping and upright position, both at the start of the examination and at the time of treatment control. If this hypertension is not controlled properly and regularly, it will automatically cause Hypertensive Heart Disease (CHD) and complications in other

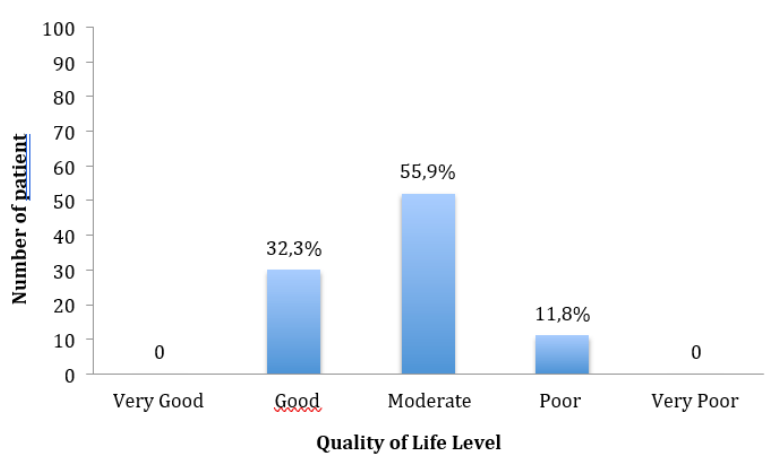

target organs as well as complications to become coronary heart disease (CHD) or heart failure [20,23].

Fig. 3. Quality of life level from elderly with hypertension.

In Fig. 3, it is found that the most quality of life experienced by elderly people with hypertension is a moderate quality of life as many as 52 people (55.9\%), 11 people $(11.8 \%)$ stated that their quality of life is poor and 30 people $(32.3 \%)$ ) have a good quality of life. Trevisol et al (Brazil, 2011) in their study suggested that there was a decrease in the quality of life in hypertensive patients compared to normotension. Quality of life is a person's perception of health, culture, social and environment which is subjective and cannot be defined with certainty $[16,17]$.

The decline in the quality of life of elderly patients with hypertension occurs because hypertension has an impact on social function, mental health, and psychological function, especially in the elderly where there is a progressive decline in physiological and cognitive functions $[6,16]$.

Decreased quality of life can be prevented by improving habits and lifestyle with healthy food and physical exercise, pharmacological interventions that can prolong life, and the ability to adapt to the progress of the times. The current concept of aging does not only focus on individual achievements in financial success, health status, or social participation. Each individual is also expected to enrich their capacity in interacting with the environment $[6,24]$. 


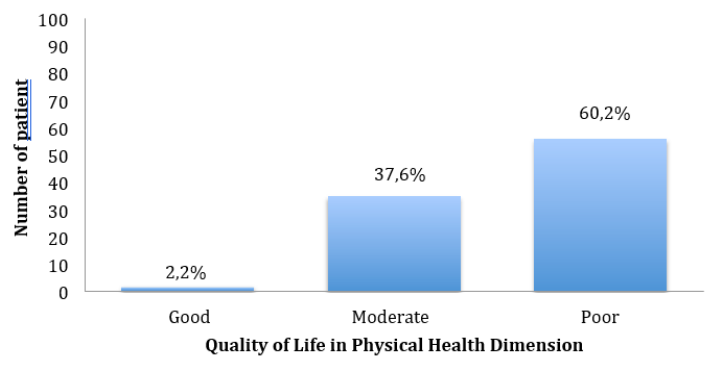

Fig. 4. Quality of life in physical health dimension.

From Fig. 4, in terms of the physical health dimension, it was found that 35 people $(37.6 \%)$ had a moderate quality of life, while the most respondents with poor quality of life were 56 people $(60.2 \%)$. Respondents who have a high quality of life in the dimensions of physical health are 2 people $(2.2 \%)$. The physical health dimension consists of pain and discomfort, energy and fatigue, sleep and rest, mobility, daily activities, dependence on medication or drugs, and the capacity to work [18].

Research conducted by Ha et al. (Vietnam, 2014) found that there was a decrease in the quality of life in physical health in rural communities in Vietnam [25].

Decreasing quality of life can also be caused by the factor of adherence to drug use so that the elderly need family support that plays an active role in the health of the elderly. Research conducted by Monika et al. (Poland, 2012) found that management was associated with the quality of life of hypertensive patients, and patients with decreased quality of life had already shown signs of complications [26-28].

The most common complaints experienced by the elderly are difficulty sleeping or insomnia. This is caused by disruption of the circadian rhythm so that the elderly often have difficulty getting to sleep or maintaining sleep, causing fatigue, drowsiness, and easily falling asleep during the day. In the elderly with hypertension, blood pressure normally decreases when sleeping and increases when waking up [20,23].

Prevention needs to be done so that the quality of life of patients increases, namely the elderly need to regulate and reduce their time in bed and need to be more active during the day, both physically and socially. In addition, a comfortable environment for sleeping and avoiding consumption of drinks or drugs that cause sleeplessness can improve the complaints of difficulty sleeping experienced by the elderly $[20,23]$.

From Fig. 5, in terms of the psychological health dimension, the highest result is that the quality of life of the respondents is bad as many as 49 people $(52.7 \%)$ while respondents with moderate quality of life are 42 people $(45.1 \%)$ and 2 people $(2.2 \%)$ have a good quality of life. Research conducted by Stanley et al (2011) stated that there was a decrease in the psychological quality of life in hypertensive patients with a percentage of $67.8 \%$. The dimensions of psychological well-being consist of positive effects, thinking, learning, memory, concentration, self-image, body image and appearance, negative effects, and spiritual or religious beliefs.

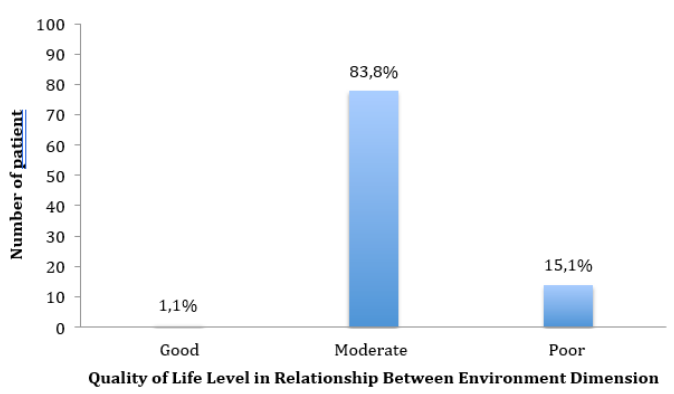

Fig. 5. Quality of life level in psychological well-being dimension.

Some respondents have problems in both the family, both the relationship between husband, wife, and their children. The burden of thoughts experienced by these elderly people exacerbates the complaints of hypertension experienced by them so that their quality of life decreases. This causes anxiety that can interfere with daily and physical activities such as difficulty sleeping or concentration problems [24].

Decreased concentration is one of the facets experienced by the elderly where one of the causes is due to an increase in blood pressure to the brain, which makes it difficult for patients to concentrate. The complaints experienced by these respondents caused a decrease in the quality of life for their psychological well-being.

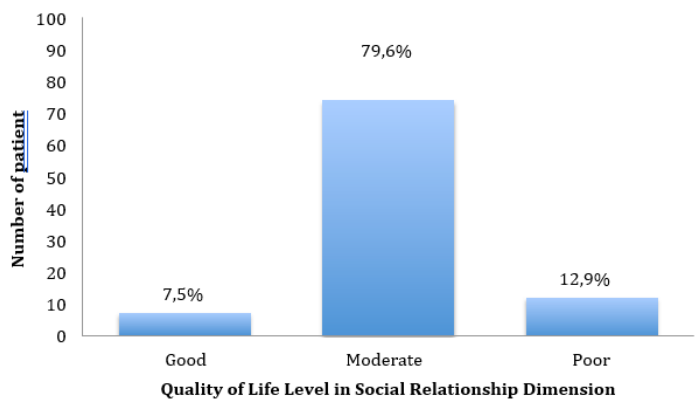

Fig. 6. Quality of life level in social relationship dimension.

From Fig. 6, the level of quality of life in the dimensions of social relations, the most respondents are quality of life as many as 74 people $(79.6 \%)$ and the least is a high quality of life as many as 7 people $(7.5 \%)$. The poor quality of life of the elderly with hypertension in the dimension of social relations was 12 people $(12.9 \%)$. The social relationship dimension consists of personal relationships, social support, and sexual activity.

Research conducted by Theodorou et al. (Cyprus, 2011) found different results where the quality of life of hypertensive patients decreased from the dimension of social relations [26]. The quality of personal life can be improved by increasing the attention of spouses, family, caregivers, and the people around them. 


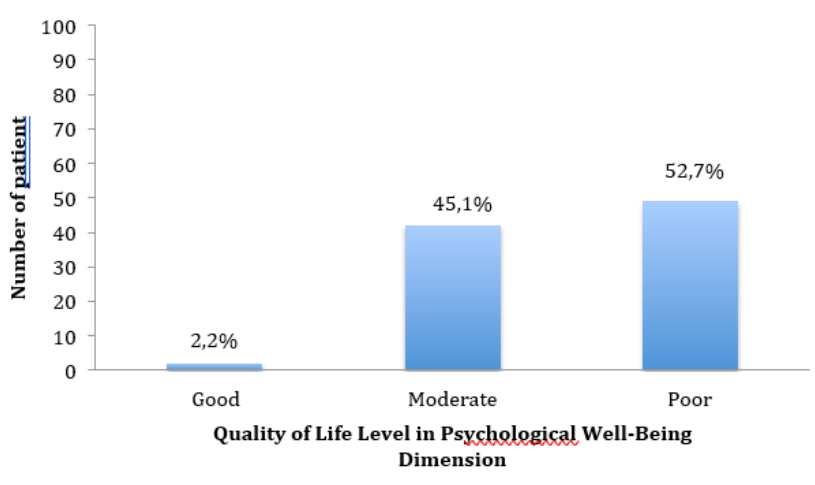

Fig. 7. Quality of life level in relationship between environment dimension.

Fig. 7 shows the results of the quality of life of respondents with a high quality of life of 1 person (1.1\%), 78 people $(83.9 \%)$ of moderate quality of life, and 14 people $(15.1 \%)$ of poor quality of life. The highest percentage of respondents found that the quality of life level is moderate, this can be caused by the limitations of the elderly so that they tend to lack recreation, limited information sources, access to health, and also poorly maintained environmental conditions. The dimensions of environmental relations consist of physical security, home environment, access and quality of care, opportunities to get new skills and information, participation and opportunities for recreation or leisure time, physical environment (pollution, noise, and traffic), and transportation.

The poor quality of life that tends to increase is caused by the elderly who live alone without their children or family, so that the elderly have difficulty if they need help. In addition, the noisy home environment and the lack of opportunities for recreation affect the decline in quality of life in the domain of environmental relationships.

\section{CONCLUSION}

From the results, the description of the quality of life from 93 elderly patients with hypertension using the WHOQOLBREF instrument at Ciereng Subang Hospital, it can be concluded that in general quality of life got a moderate quality of life $(55.9 \%)$, the dimensions of physical health got a poor quality of life $(60.2 \%)$, the dimensions of psychological wellbeing got a poor quality of life (52.7\%), the social relationship dimension being got a moderate quality of life $(79.6 \%)$ and on the relation between environmental dimension got a moderate quality of life (83.8\%).

Further research on other factors that affect the quality of life of elderly patients with hypertension is needed, such as subject characteristics, the presence of other chronic diseases, and hypertensive elderly compliance in taking medication.

\section{REFERENCES}

[1] World Health Organization (WHO), The uses of epidemiology in the study of elderly. Geneva: WHO, 1984.
[2] R.B. Darmojo, "Demografi dan epidemiologi populasi lanjut usia," In H.H. Martono and K. Pranarka, editor. Buku ajar Boedhi-Darmojo GERIATRI, Edisi 5. Jakarta: Badan Penerbit Fakultas Kedokteran Universitas Indonesia, 2013, pp. 40-60.

[3] United Nations (UN), World Population Ageing 2013. New York: United Nations, 2013

[4] R.B. Darmojo, "Gerontologi dan geriatri di Indonesia," In: S. Setiadi, I. Alwi, A.W. Sudoyo, K. Simadibrata, B. Setiyohadi, dan A.F. Syam, editor. Buku Ajar Ilmu Penyakit Dalam, Jilid 1. Jakarta: Pusat Penerbitan Departemen Ilmu Penyakit Dalam FK UI, 2009, pp. 924-33

[5] Badan Pusat Statistik (BPS), Statistik Penduduk Lanjut Usia 2014. Jakarta: BPS, 2014.

[6] Depkes, Info Datin Pusat Data dan Informasi Kementerian Kesehatan RI. Situasi dan Analisis Lanjut Usia. Jakarta: Depkes, 2014.

[7] S. Setiati, Geriatric medicine, sarkopenia, frailty dan kualitas hidup pasien usia lanjut: tantangan masa depan pendidikan, penelitian dan pelayanan kedokteran di Indonesia. Jakarta: Fakultas Kedokteran Universitas Indonesia, 2013.

[8] R.B. Darmojo dan M.H. Martono, "Teori proses menua," In: H.H Martono dan K. Pranarka, editor. Buku ajar Boedhi-Darmojo GERIATRI, Edisi 5. Jakarta: Badan Penerbit Fakultas Kedokteran Universitas Indonesia, 2013, pp. 7-19.

[9] M. Yogiantoro, "Pendekatan klinis hipertensi," In: S. Setiadi, I. Alwi, A.W. Sudoyo, K. Simadibrata, B. Setiyohadi, dan A.F. Syam, editor. Buku Ajar Ilmu Penyakit Dalam, Jilid 3. Jakarta: Pusat Penerbitan Departemen Ilmu Penyakit Dalam FK UI, 2014, pp. 2259-83.

[10] P.A. James, S. Oparil, B.L. Carter, W.C. Cushman, C. DennisonHimmelfarb, J. Handler, ... and E. Ortiz, "2014 evidence-based guideline for the management of high blood pressure in adults: report from the panel members appointed to the Eighth Joint National Committee (JNC 8)," Jama, vol. 311, no. (5), pp. 507-520, 2014

[11] F. Rinawang, Faktor-faktor yang berhubungan dengan hipertensi pada kelompok lanjut usia di Kelurahan Sawah Baru Kecamatan Ciputat, Kota Tangerang Selatan Tahun 2011. Jakarta: Fakultas Kedokteran dan Ilmu Kesehatan Universitas Islam Negeri Syarif Hidayatullah Jakarta, 2011.

[12] Suhardjono, "Hipertensi pada usia lanjut," In: S. Setiadi, I. Alwi, A.W Sudoyo, K. Simadibrata, B. Setiyohadi, dan A.F. Syam, editor. Buku Ajar Ilmu Penyakit Dalam. Jilid 3. Jakarta: Pusat Penerbitan Departemen Ilmu Penyakit Dalam FK UI, 2014, pp. 3855-3858.

[13] A.V. Chobanian, G.L. Bakris, H.R. Black, W.C. Cushman, L.A. Green, J.L. Izzo Jr, ... and National High Blood Pressure Education Program Coordinating Committee," The seventh report of the joint national committee on prevention, detection, evaluation, and treatment of high blood pressure: the JNC 7 report," Jama, vol. 289, no. (19), pp. 25602571, 2003

[14] Badan Penelitian dan Pengembangan Kesehatan Kementerian Kesehatan RI, Riset Kesehatan Dasar (Riskesdas) 2013. Jakarta: BPPKKK RI, 2013.

[15] Badan Penelitian dan Pengembangan Kesehatan Kementerian Kesehatan RI, Pokok-pokok Hasil Riset Kesehatan Dasar Provinsi Jawa Barat Tahun 2013. Jakarta: BPPKKK RI, 2013.

[16] D.J. Trevisol, L.B. Moreira, A. Kerkhoff, S.C. Fuchs, and F.D. Fuchs, "Health-related quality of life and hypertension: a systematic review and meta-analysis of observational studies," Journal of hypertension, vol. 29, no. (2), pp. 179-188, 2011

[17] P.R. Dewi dan I.W. Sudhanan, Gambaran kualitas hidup pada lansia dengan normotensi dan hipertensi di wilayah kerja Puskesmas Gianyar I Periode bulan November Tahun 2013. Udayana: Bagian Ilmu Penyakit Dalam FK Udayanan RSUP Sanglah, 2013.

[18] WHOQOL Group, Development of the world health organization WHOQOL-BREF Quality of Life Assessment. Cambridge: Psychological Medicine, Cambridge University Press, 1998.

[19] O.C. Salim, N.I. Sudharma, R.K. Kusumaratna, and A. Hidayat, "Validitas dan reliabilitas World Health Organization Quality of Life- 
BREF untuk mengukur kualitas hidup lanjut usia," Universa Medicina, vol. 26, no. (1), pp. 27-38, 2007.

[20] M.H. Martono, “Aspek Fisiologik dan Patologik Akibat Proses Menua,' In: H.H. Martono dan K. Pranarka, editor. Buku ajar Boedhi-Darmojo GERIATRI, Edisi 5. Jakarta: Badan Penerbit Fakultas Kedokteran Universitas Indonesia, 2013, pp. 61-79.

[21] C. Irwanadi, "Hipertensi Primer," In: S. Setiadi, I. Alwi, A.W. Sudoyo, K. Simadibrata, B. Setiyohadi, dan A.F. Syam, editor. Buku Ajar Ilmu Penyakit Dalam, Jilid 2. Jakarta: Pusat Penerbitan Departemen Ilmu Penyakit Dalam FK UI, 2014.

[22] R Maranon and J.F. Reckelhoff, "Sex and gender differences in control of blood pressure," National Institutes of Health, vol. 125, no. (7), pp. 311-318, 2013.

[23] N. Amir, Gangguan tidur pada lanjut usia. Jakarta: Bagian Psikiatri Fakultas Kedokteran Universitas Indonesia, 2007.

[24] S. Setiati, K. Harimurti, dan A Govinda. "Proses Menua dan Implikasi Kliniknya," In: S. Setiadi, I. Alwi, A.W. Sudoyo, K. Simadibrata, B.
Setiyohadi, dan A.F. Syam, editor. Buku Ajar Ilmu Penyakit Dalam FK UI, Edisi VI. Jakarta: Interna Publishing, 2104, pp. 3669-79.

[25] N.T. Ha, H.T. Duy, N.H. Le, V. Khanal, and R. Moorin, "Quality of life among people living with hypertension in a rural Vietnam community," BMC public health, vol. 14, no. (1), pp. 1-9, 2014.

[26] World Health Organization, WHOQOL-BREF US English Version. United States of America: WHO, 1997. [Online]. Retrieved from: http://depts.washington.edu/seaqol/docs/WHOQOLBREF\%20with\%20s coring\%20instructions_Updated\%2001-10-14.pdf [Accessed on: March 26th, 2021].

[27] M. Zygmuntowicz, A. Owczarek, A. Elibol, and J. Chudek, "Comorbidities and the quality of life in hypertensive patients," Pol Arch Med Wewn, vol. 122, no. (7-8), pp. 333-40, 2012.

[28] A.A. Dian, W. Annes, S. Edward, A. Hendra, and S.S. Silvia, Faktorfaktor yang berhubungan dengan kejadian hipertensi pada pasien yang berobat di Klinik Dewasa Puskesmas Bangkinang Periode Januari sampai Juni 2008. Pekanbaru: Universitas Riau, 2011. 